\title{
Humoral biomarkers of latex allergy
}

\author{
Pedro Giavina-Bianchi ${ }^{1}$, Laila Sabino Garro ${ }^{2}$, Marcelo Vivolo Aun ${ }^{2}$, Antonio Abílio Motta ${ }^{2}$, Mariana Castells ${ }^{3 *}$, \\ Jorge Kalii ${ }^{2}$ \\ From 6th Drug Hypersensitivity Meeting (DHM 6) \\ Bern, Switzerland. 9-12 April 2014
}

\section{Background}

Although latex allergy is decreasing in several countries, it is still a global health problem that is associated with life-threatening reactions. The main objective of this study is to identify clinical and laboratory factors associated with sensitization and allergy to latex, including latex-specific IgE, IgG4 and IgA.

\section{Method}

Observational study in a cohort of 400 children and adolescents with defect of neural tube closure. Patients underwent clinical interview and had their blood drawn to measure specific serum IgE, IgG4 and IgA to latex. The prevalence of sensitization and allergy to latex were calculated and possible associations with clinical and laboratory variables were analyzed.

\section{Results}

The prevalence of sensitization and allergy to latex in patients presenting defects in neural tube closure was $33.2 \%$ and $12.2 \%$, respectively. Cutaneous manifestations of latex allergy were the most common (79.6\%), but anaphylaxis was observed in $4.75 \%$ of patients. Clinical and surgical factors associated with latex allergy were identified and a symptom score to screening patients was developed. Concentration of specific IgE to latex $>0.77 \mathrm{kUA} / \mathrm{l}$ presented good accuracy in differentiating asymptomatic sensitization from allergy. Measurement of specific IgE to recombinant allergens also showed good accuracy in the diagnosis of allergy. The specific serum IgG4 concentration was negatively associated with allergy to latex, but this was not observed for specific IgA.

\section{Conclusion}

Higher concentration of specific IgE to latex and Hevb5, lower concentration of specific IgG4 to latex and symptom score ${ }_{i} \hat{Y} 40 \%$ were associated with latex allergy.

\section{Authors' details \\ 'University of Sao Paulo, Clinical Immunology and Allergy, USA. ${ }^{2}$ University of Sao Paulo, Clinical Immunology and Allergy, Brazil. ${ }^{3}$ Harvard Medical School, Division of Rheumatology, Allergy and Immunology, Department of Medicine, BWH, USA.}

Published: 18 July 2014

doi:10.1186/2045-7022-4-S3-P128

Cite this article as: Giavina-Bianchi et al: Humoral biomarkers of latex allergy. Clinical and Translational Allergy 2014 4(Suppl 3):P128.
Submit your next manuscript to BioMed Central and take full advantage of:

- Convenient online submission

- Thorough peer review

- No space constraints or color figure charges

- Immediate publication on acceptance

- Inclusion in PubMed, CAS, Scopus and Google Scholar

- Research which is freely available for redistribution

Submit your manuscript at www.biomedcentral.com/submit
() Biomed Central
C Biomed Central

(c) 2014 Giavina-Bianchi et al; licensee BioMed Central Ltd. This is an Open Access article distributed under the terms of the Creative Commons Attribution License (http://creativecommons.org/licenses/by/4.0), which permits unrestricted use, distribution, and reproduction in any medium, provided the original work is properly cited. The Creative Commons Public Domain Dedication waiver (http://creativecommons.org/publicdomain/zero/1.0/) applies to the data made available in this article, unless otherwise stated. 